\title{
The induction of oxidative enzymes in Streptomyces coelicolor upon hydrogen peroxide treatment
}

\author{
Jong-Soo Lee, Yung-Chil HaH and Jung-Hye RoE*
}

Department of Microbiology, College of Natural Sciences, and Research Center for Molecular Microbiology, Seoul National University, Seoul 151-742, Korea

(Received 25 August 1992; revised 6 January 1993; accepted 27 January 1993)

\begin{abstract}
Streptomyces coelicolor (Müller) became resistant to killing by hydrogen peroxide $\left(\mathrm{H}_{2} \mathrm{O}_{2}\right)$ when pretreated with non-lethal concentrations of $\mathrm{H}_{2} \mathrm{O}_{2}$. When rapidly growing cells were pretreated with $100 \mu \mathrm{M}-\mathrm{H}_{2} \mathrm{O}_{2}$, they became 7-10-fold more resistant to $20 \mathrm{mM}-\mathrm{H}_{2} \mathrm{O}_{2}$ than were naive cells. Activities of several oxidative defense enzymes were measured in cells treated with $100 \mu \mathrm{M}-\mathrm{H}_{2} \mathrm{O}_{2}$ in either exponential or stationary phase growth. The specific activity of catalase in crude extracts of cells pretreated in either phase increased about $\mathbf{4 0} \%$. Peroxidase activity, in cell extracts and culture supernatants, respectively, of cells treated in the stationary growth phase increased two times and four times. Glucose-6-phosphate dehydrogenase increased by $60 \%$ at the exponential growth phase. Glutathione reductase increased $80 \%$ after treatment in the exponential phase and 4-fold in the stationary growth phase. However, superoxide dismutase activity decreased by $70 \%$. Two mutants resistant to $\mathrm{H}_{2} \mathrm{O}_{2}$ were isolated after mutagenesis of spores with $N$-methyl- $N^{\prime}$-nitro- $N$-nitrosoguanidine. In addition to a dramatic increase in the survival rate in $20 \mathrm{mM}-\mathrm{H}_{2} \mathrm{O}_{2}$, both mutants exhibited increased activities of all the above enzymes except superoxide dismutase. The pleiotropic phenotype of the mutants suggests that there exists a global regulation of oxidative response in $S$. coelicolor.
\end{abstract}

\section{Introduction}

All aerobic organisms must cope with reactive oxygen species such as the superoxide anion $\left(\mathrm{O}_{2}^{-}\right)$, hydrogen peroxide $\left(\mathrm{H}_{2} \mathrm{O}_{2}\right)$ and the hydroxyl radical $\left(\mathrm{HO}^{*}\right)$, produced as incomplete reduction products of molecular oxygen, and with singlet oxygen formed photochemically (Cadenas, 1989; Morgan et al., 1986; Halliwell, 1990). Bacteria grown aerobically encounter these oxidants not only from inside the cell, but also from outside, as occurs, for example, when pathogenic bacteria are attacked by phagocytic cells (Hassett \& Cohen, 1989). The reactive oxygen species can oxidize membrane fatty acids and proteins, and can damage DNA (Morgan et $a l ., 1986$; Saran \& Bors, 1990). The responses of bacterial cells to these oxidative stresses have been studied mostly in Escherichia coli and Salmonella typhimurium (Storz et al., 1990; Farr \& Kogoma, 1991).

Several oxidative defence proteins and their genes have been found in E. coli (Storz et al., 1989, 1990; Farr

*Author for correspondence. Tel. 28806706 ; fax 28884911.

Abbreviation: SOD, superoxide dismutase.
\& Kogoma, 1991). These include defence (radicalscavenging) enzymes such as superoxide dismutase (SOD) ( $\operatorname{sod} A, \operatorname{sodB})$, catalase (katG, katE), alkylhydroperoxide reductase $(a h p C, a h p F)$ and glutathione reductase $(\operatorname{gor} A)$. Several DNA enzymes such as exonuclease III ( $x$ th $A$ ), endonuclease IV (nfo) and other endonucleases ( $r e c B, r e c C)$, as well as some metabolic enzymes such as NADH dehydrogenase $(n d h)$ and glucose-6-phosphate dehydrogenase $(z w f)$ are also involved in oxidative defence. These enzymes might repair DNA damage caused by $\mathrm{H}_{2} \mathrm{O}_{2}$ or $\mathrm{HO}^{*}$ radicals (Imlay et al., 1988; Imlay \& Linn, 1988), protect cells from membrane damage such as lipid peroxidation (Farr et al., 1988), or lower the reducing equivalents to prevent generation of harmful $\mathrm{HO}^{*}$ radicals in the presence of metal and reducing equivalents (Imlay et al., 1988). The evolution of such defence mechanisms in order to prevent or repair oxidative damage must have been critical to the survival of aerobic life forms (Halliwell \& Gutteridge, 1989).

Induction of the defence proteins by treating cells with low doses of $\mathrm{H}_{2} \mathrm{O}_{2}$ or radical-producing oxidants provides the basis for adaptation as well as resistance to the oxidants. Several regulatory proteins mediate expression 
of the genes for these proteins. The genes induced by superoxide-generating compounds such as paraquat, plumbagin or menadione include $\operatorname{sod} A$ and $z w f$, and are all controlled by the regulator SoxR (Tsaneva \& Weiss, 1990). The genes induced by $\mathrm{H}_{2} \mathrm{O}_{2}$ include kat $G$, ahpC, $a h p F$ and gor $A$, and are all controlled by the positive regulator OxyR (Christman et al., 1985, 1989; Morgan et $a l ., 1986)$. The so-called sox $R$ and $o x y R$ regulons seem to overlap other stress response regulons such as that for heat-shock, since some proteins are induced in common by different stresses (Greenberg \& Demple, 1989; VanBogelen et al., 1987), and some cross-protection has been observed (Christman et al., 1985; Jenkins et al., 1988).

Compared with E. coli and S. typhimurium, little is known about these systems in Bacillus subtilis, and even less in other bacteria. In B. subtilis, several proteins are induced by $\mathrm{H}_{2} \mathrm{O}_{2}$ (Murphy et al., 1987), and the sensitivity of $B$. subtilis to $\mathrm{H}_{2} \mathrm{O}_{2}$ is growth-cycle-dependent. Increased sensitivity in certain sporulation mutants has also been reported (Dowds et al., 1987; Bol \& Yasbin, 1990).

We have tried to elucidate the regulation of defences against oxidative stress in Streptomyces coelicolor (Müller). This paper presents a biochemical analysis of the adaptation to $\mathrm{H}_{2} \mathrm{O}_{2}$ in $S$. coelicolor, and some evidence for a global genetic system that controls the expression of many defence enzymes in this organism.

\section{Methods}

Media and culture conditions. Growth and maintenance of $S$. coelicolor (Müller) (ATCC 10147) were essentially as described by Hopwood et al. (1985). S. coelicolor was grown routinely in minimal or YEME media (Hopwood et al., 1985) at $30^{\circ} \mathrm{C}$ with shaking. The growth phase of cultures was determined by measuring growth as $\mathrm{OD}_{640}$, dried mycelium weight or DNA content (Baserga, 1989).

For adaptation experiments in the early exponential growth phase, germinated spores were used to inoculate fresh minimal media to an $\mathrm{OD}_{600}$ of 0.03-0.05. After cultures had been incubated with shaking for $3 \mathrm{~h}$ at $30^{\circ} \mathrm{C}_{,} \mathrm{H}_{2} \mathrm{O}_{2}$ was added to a final concentration of $100 \mu \mathrm{M}$ and the cultures were kept at $30^{\circ} \mathrm{C}$ for $1 \mathrm{~h}$. The cultures were then challenged with $\mathrm{H}_{2} \mathrm{O}_{2}$ at final concentrations up to $20 \mathrm{~mm}$. Samples were withdrawn at $10 \mathrm{~min}$ intervals, and diluted immediately in minimal medium; aliquots were plated on nutrient agar and incubated for $2 \mathrm{~d}$ at $30{ }^{\circ} \mathrm{C}$ to count viable cells.

For adaptation experiments in the mid-exponential growth phase, spores were used to inoculate YEME media. Following growth for $36-40 \mathrm{~h}$, mycelia were collected by centrifugation and resuspended in minimal medium. $\mathrm{H}_{2} \mathrm{O}_{2}$ was added to a final concentration of $100 \mu \mathrm{M}$ and the cultures were incubated without shaking at $30^{\circ} \mathrm{C}$ for $30 \mathrm{~min}$. The cultures were then challenged with $\mathrm{H}_{2} \mathrm{O}_{2}$ as above. Protoplasts were obtained as described by Hopwood et al. (1985). Dilutions were made in P buffer (Hopwood et al., 1985), and aliquots of diluted cells were plated on R2YE regeneration medium. They were incubated for $2 \mathrm{~d}$ at $30^{\circ} \mathrm{C}$ to count viable and regenerated cells.

For enzyme assays, germinated spores were used to inoculate minimal medium and the cultures were grown for $40-48 \mathrm{~h}$, when their $\mathrm{OD}_{640}$ was $0 \cdot 9-1 \cdot 2$ (exponential growth phase) or for $7-10 \mathrm{~d}$ (stationary growth phase). The production of both blue and red pigments was regarded as an indication of entry into the stationary growth phase. The mycelium and DNA content of stationary phase cultures decreased by $20-60 \%$.

Preparation of cell extracts. Mycelium was harvested by centrifugation at $3000 \mathrm{~g}$ for $10 \mathrm{~min}$ and was washed twice with $10 \mathrm{mM}$-potassium phosphate buffer ( $\mathrm{pH} 7 \cdot 0$ ). The washed mycelium was suspended in 50 mM-potassium phosphate buffer $(\mathrm{pH} \mathrm{7.0)}$ containing 1 mM-phenylmethylsulphonyl fluoride and was disrupted by abrasion with glass beads for $5 \mathrm{~min}$ in a mini-bead beater (Biospec) at the maximum power setting. The cell debris was pelleted at 12000 r.p.m. for $15 \mathrm{~min}$ in a microcentrifuge. Cells and extracts were maintained at $4{ }^{\circ} \mathrm{C}$ throughout the procedures described above.

Enzyme assays. Catalase activity in extracts was determined as described by Beers \& Sizer (1952). The rate of disappearance of $\mathrm{H}_{2} \mathrm{O}_{2}$ was measured spectrophotometrically at $240 \mathrm{~nm}$. The reaction mixture contained $12 \mu \mathrm{l} 3 \%(\mathrm{v} / \mathrm{v}) \mathrm{H}_{2} \mathrm{O}_{2}$ and an appropriate amount of enzyme in $50 \mathrm{~mm}$-potassium phosphate buffer $(\mathrm{pH} \mathrm{7.0)}$ ) in a $1.0 \mathrm{ml}$ total volume. The assay was done at $30^{\circ} \mathrm{C}$ in quartz cuvettes of $1 \mathrm{~cm}$ path length. One unit of enzyme was defined as the activity that catalysed the degradation of $1 \mu \mathrm{mol} \mathrm{H}_{2} \mathrm{O}_{2} \min ^{-1}$.

Peroxidase activity in cell extracts and culture supernatants was measured spectrophotometrically by monitoring the oxidation of $o$ dianisidine at $460 \mathrm{~nm}$ in the presence of $\mathrm{H}_{2} \mathrm{O}_{2}$ (Kapoor \& Sveenivasan, 1988). The reaction mixture contained $10 \mu \mathrm{l} 3 \mathrm{M}$-sodium acetate buffer (pH 4.8), $10 \mu \mathrm{l} \mathrm{H}_{2} \mathrm{O}_{2}$ and $10 \mu \mathrm{l} 0.044 \%$-dianisidine, in a $1.0 \mathrm{ml}$ total volume. One unit of enzyme was defined as the activity that increased the $A_{460}$ by $0.01 \mathrm{~min}^{-1}$

The assay for superoxide dismutase (SOD) (Beauchamp \& Fridovich, 1971) was based on the transfer of electrons by xanthine oxidase to nitroblue tetrazolium (NBT) via oxygen. This reduction of NBT is inhibited by SOD. The reaction mixture contained $0.1 \mathrm{mM}$-xanthine, $25 \mu \mathrm{M}-\mathrm{NBT}, 0.1 \mathrm{~mm}-\mathrm{EDTA}$ and $0.01 \%(\mathrm{w} / \mathrm{v})$ xanthine oxidase, in $50 \mathrm{~mm}$-sodium carbonate buffer $(\mathrm{pH} \mathrm{10} \cdot 2)$. The initial rate of reduction of NBT in reaction mixtures with and without SOD was followed by measuring the $A_{560}$. The amount of SOD activity causing $50 \%$ inhibition was defined as one unit.

Glutathione reductase activity in crude extracts was measured by the modified procedure of Smith et al. (1988). This is based on the increase in $A_{412}$ when 5,5'-dithiobis(2-nitrobenzoic acid) (DTNB) is reduced by reduced glutathione (GSH), produced by glutathione reductase. The reaction mixture contained $1 \mathrm{~mm}$-EDTA, $0.3 \mathrm{~mm}$-DTNB, $0.1 \mathrm{~mm}-$ NADPH and 1 mm-oxidized glutathione (GSSG), in $200 \mathrm{~mm}-$ potassium phosphate buffer $(\mathrm{pH} 7 \cdot 5)$. A unit of activity was defined as the amount that catalysed the production of $1 \mu \mathrm{mol}$ thiobis(2-nitrobenzoic acid) (TNB) $\mathrm{min}^{-1}$.

Glucose-6-phosphate dehydrogenase was measured using protocols outlined in the Worthington Manual (Decker, 1977), as the rate of reduction of NADP monitored at $340 \mathrm{~nm}$. The assay mixture contained $30 \mu \mathrm{l} 32 \mathrm{~mm}$-glucose 6-phosphate in $100 \mathrm{~mm}$-Tris/ $\mathrm{HCl}$ (pH 7.5), $10 \mu \mathrm{l}$ $23 \mathrm{~mm}-\mathrm{NADP}$ in $1 \%$ sodium bicarbonate, and enzyme solution in a $1.0 \mathrm{ml}$ total reaction volume. One unit of enzyme was defined as the activity that catalysed the reduction of $1 \mu \mathrm{mol}$ NADP min $^{-1}$.

Mutagenesis with $N$-methyl- $N^{\prime}$-nitro-N-nitrosoguanidine $(N T G)$ and screening for $\mathrm{H}_{2} \mathrm{O}_{2}$-resistant mutants. Spores were treated with NTG ( $1 \mathrm{mg}$ or $3 \mathrm{mg} \mathrm{ml}^{-1}$ ) to a survival ratio of $0 \cdot 1-10 \%$ and then plated on Bennet's medium (Jones, 1949), presoaked with $30 \mathrm{~mm}-\mathrm{H}_{2} \mathrm{O}_{2}$ for $30 \mathrm{~min}$. Spores of surviving colonies were collected to test resistance to $\mathrm{H}_{2} \mathrm{O}_{2}$. About $10^{5}$ spores from each colony were spread in parallel rows on Bennet's medium. After $5 \mathrm{~h}$, a strip of filter paper soaked with $3 \%$ ( $880 \mathrm{mM}) \mathrm{H}_{2} \mathrm{O}_{2}$ was placed at $90^{\circ}$ across the centre of the inoculated streaks and incubation was continued for $2 \mathrm{~d}$. Mutants that grew closer to the strip than the wild-type were collected. For disk tests, around $10^{6}$ spores from each mutant were plated on Bennet's medium; $5 \mathrm{~h}$ later $60 \mu \mathrm{l} 30 \% \mathrm{H}_{2} \mathrm{O}_{2}$ absorbed on a filter disk was placed at the centre of a 
plate. Mutants that grew closer to the disc than the wild type were chosen.

\section{Results and Discussion}

\section{Adaptation to $\mathrm{H}_{2} \mathrm{O}_{2}$ stress}

We tested the sensitivity of $S$. coelicolor to $\mathrm{H}_{2} \mathrm{O}_{2}$ as well as its adaptation in early and mid-exponential growth phases. In the adaptation experiments, we pretreated cells with a non-lethal concentration $(100 \mu \mathrm{M})$ of $\mathrm{H}_{2} \mathrm{O}_{2}$ for $1 \mathrm{~h}$ before exposure to a lethal concentration (20 mM). To obtain viable cell counts by plating, we grew cultures in minimal medium for $3 \mathrm{~h}$ after inoculation with germinated spores. The viability of cells in $20 \mathrm{~mm}-$ $\mathrm{H}_{2} \mathrm{O}_{2}$ was counted at $10 \mathrm{~min}$ intervals after plating. The results (Fig. 1) demonstrate that only $0 \cdot 1 \%$ of the cells remained viable after $30 \mathrm{~min}$ in $20 \mathrm{mM}-\mathrm{H}_{2} \mathrm{O}_{2}$. However, when cells were pretreated with $\mathrm{H}_{2} \mathrm{O}_{2}$, survival was enhanced almost 10-fold.

The extent of adaptation was similar when cells were grown to mid-exponential phase and counted as regenerated protoplasts after $\mathrm{H}_{2} \mathrm{O}_{2}$ treatment. The results suggest that the pretreatment with $100 \mu \mathrm{M}-\mathrm{H}_{2} \mathrm{O}_{2}$ caused mycelial cells to adapt better to a higher dose of $\mathrm{H}_{2} \mathrm{O}_{2}$, showing a survival rate seven times higher than naive cells against $20 \mathrm{~mm}-\mathrm{H}_{2} \mathrm{O}_{2}$ (Fig. 2). Since the colonies went through lysozyme treatment and regeneration in addition to $\mathrm{H}_{2} \mathrm{O}_{2}$ treatment, we cannot quantitatively estimate the $\mathrm{H}_{2} \mathrm{O}_{2}$ sensitivity or adaptation. However, the results point to qualitatively similar adaptations in earlyexponential and mid-exponential growth phases.

The adaptation of $\mathrm{H}_{2} \mathrm{O}_{2}$ in $S$. coelicolor occurred under conditions slightly harsher than those previously described for $E$. coli (Demple et al., 1983), S. typhimurium (Christman et al., 1985) and B. subtilis (Dowds et al., 1987). Pretreatment with 60 and $50 \mu \mathrm{M}-\mathrm{H}_{2} \mathrm{O}_{2}$ increased survival against $10 \mathrm{~mm}-\mathrm{H}_{2} \mathrm{O}_{2}$ by approximately 50 - and 100 -fold, in E. coli and in B. subtilis, respectively.

\section{Adaptation is accompanied by induction of several enzyme activities involved in defence against oxidative stress}

The specific activities of several oxidoreductases and free-radical scavenging enzymes known to function in protection against oxidative stress were measured (Table 1). Cells in the exponential and stationary growth phases were treated with $100 \mu \mathrm{M}-\mathrm{H}_{2} \mathrm{O}_{2}$ for $30 \mathrm{~min}$. The specific activity of catalase in crude extracts of treated cells increased about $40 \%$ above that in untreated cells at both exponential and stationary phases. This is a smaller response than the 4-5-fold induction of catalase activity in E. coli (Christman et al., 1985) and S. typhimurium (Finn \& Condon, 1975). The constitutive level of catalase

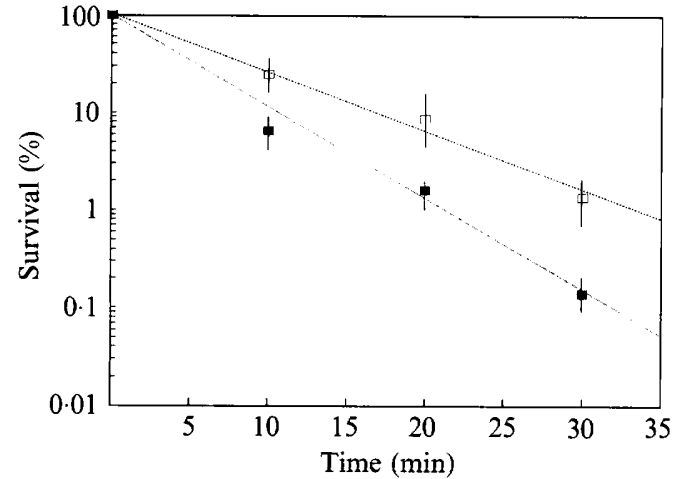

Fig. 1. Survival of $S$. coelicolor in early exponential growth phase following treatment with $20 \mathrm{~mm}-\mathrm{H}_{2} \mathrm{O}_{2}$. Pregerminated spores were used to inoculate minimal medium, and were grown at $30^{\circ} \mathrm{C}$ with shaking for $3 \mathrm{~h}$. Some cells were pretreated with $100 \mu \mathrm{M}-\mathrm{H}_{2} \mathrm{O}_{2}$ for $1 \mathrm{~h}$. Both pretreated $(\square)$ and naive ( $\square$ ) cells were then treated with $20 \mathrm{mM}-\mathrm{H}_{2} \mathrm{O}_{2}$. Samples taken at $10 \mathrm{~min}$ intervals were plated on nutrient agar. Each point represents the mean of three experiments with error bars showing standard deviations.

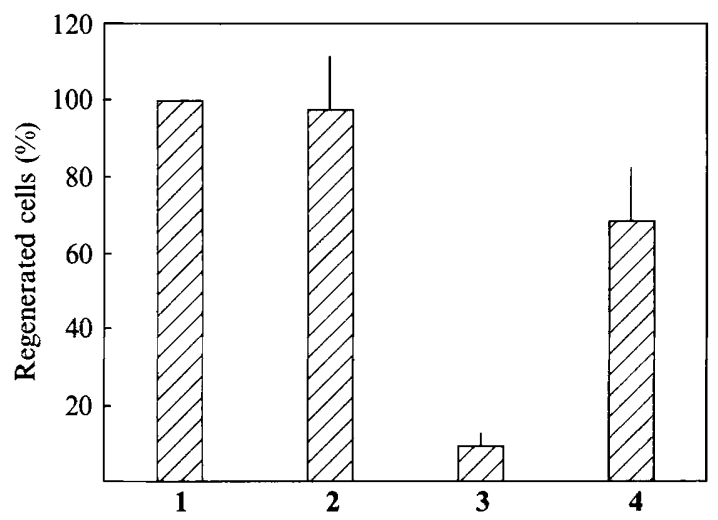

Fig. 2. Survival of $S$. coelicolor in mid-exponential growth phase following treatment with $\mathrm{H}_{2} \mathrm{O}_{2}$. Survival was measured by counting regenerated protoplasts (1) without any $\mathrm{H}_{2} \mathrm{O}_{2}$ treatment (regarded as $100 \%$ ); (2) after treatment with $100 \mu \mathrm{M}-\mathrm{H}_{2} \mathrm{O}_{2}$ for $30 \mathrm{~min}$; (3) after treatment with $20 \mathrm{mM}-\mathrm{H}_{2} \mathrm{O}_{2}$ for $30 \mathrm{~min}$; or (4) after pretreatment with $100 \mu \mathrm{M}-\mathrm{H}_{2} \mathrm{O}_{2}$ for $30 \mathrm{~min}$ and then with $20 \mathrm{mM}-\mathrm{H}_{2} \mathrm{O}_{2}$ for another $30 \mathrm{~min}$. Each result represents the mean of three experiments with error bars giving standard deviations.

activity in $S$. coelicolor was about 7-fold and 4-fold higher than that in $E$. coli and $B$. subtilis, respectively (data not shown).

Peroxidase activity was not induced in the exponential and stationary growth phases by treatment with $100 \mu \mathrm{M}-$ $\mathrm{H}_{2} \mathrm{O}_{2}$ (Table 1). However, it increased 2-fold in extracts of treated cells from cultures more than 2 weeks old. Peroxidase activity in cell-free supernatants from cultures treated at this later stationary growth phase was 4-fold higher than in untreated cells. It is not known whether the activity in the culture supernatants originated from active secretion or from passive release due to cell damage. 
Table 1. Changes in specific activity $\left(U \mathrm{mg}^{-1}\right)$ of defence enzymes following treatment with $100 \mu \mathrm{M}-\mathrm{H}_{2} \mathrm{O}_{2}$

Exponential phase activities were measured in extracts from cells grown for $40-48 \mathrm{~h}$ in minimal medium until $\mathrm{OD}_{640}$ reached $0 \cdot 9-1 \cdot 2$; stationary phase activities were measured from cells grown for 7-10 $\mathrm{d}$ in minimal medium until both red and blue pigments were produced. - , Untreated cells: + , cells treated with $100 \mu \mathrm{M}-\mathrm{H}_{2} \mathrm{O}_{2}$ for $30 \mathrm{~min}$. Values are means \pm standard deviations from more than six experiments.

\begin{tabular}{|c|c|c|c|c|c|}
\hline \multirow{2}{*}{ Enzyme } & \multirow{2}{*}{$\begin{array}{l}\mathrm{H}_{2} \mathrm{O}_{2} \\
\text { treatment ... }\end{array}$} & \multicolumn{2}{|c|}{ Exponential phase } & \multicolumn{2}{|c|}{ Stationary phase } \\
\hline & & - & + & - & + \\
\hline \multicolumn{2}{|l|}{ Catalase } & $634 \pm 51$ & $880 \pm 114$ & $690 \pm 8$ & $1003 \pm 56$ \\
\hline \multicolumn{6}{|c|}{ Peroxidase } \\
\hline \multicolumn{2}{|c|}{ Cellular } & $2 \cdot 1 \pm 0 \cdot 3$ & $\begin{array}{l}2 \cdot 0 \pm 0 \cdot 3 \\
3 \cdot 8 \pm 0 \cdot 2^{*}\end{array}$ & $\begin{array}{l}2 \cdot 4 \pm 0 \cdot 2 \\
7 \cdot 7 \pm 0 \cdot 4^{*}\end{array}$ & $2 \cdot 9 \pm 0 \cdot 3$ \\
\hline \multicolumn{2}{|c|}{ Extracellular } & ND & ND & $7 \pm 1^{*}$ & $26 \pm 3^{*}$ \\
\hline \multicolumn{2}{|c|}{$\begin{array}{l}\text { Glucose-6-phosphate } \\
\text { dehydrogenase }\end{array}$} & $6 \cdot 4 \pm 3 \cdot 0$ & $10 \cdot 5 \pm 5 \cdot 1$ & ND & ND \\
\hline \multicolumn{2}{|c|}{ Glutathione reductase } & $508 \pm 233$ & $923 \pm 226$ & $200 \pm 46$ & $830 \pm 128$ \\
\hline \multicolumn{2}{|c|}{ Superoxide dismutase } & $28 \cdot 5 \pm 6 \cdot 2$ & $8 \cdot 8 \pm 1 \cdot 6$ & NT & NT \\
\hline
\end{tabular}

NT, Not tested; ND, not detected.

* Activities from cells grown for $14-21 \mathrm{~d}$ in minimal medium.

Reduced glutathione is thought to play a role in preventing excessive damage from toxic oxygen species (Penninckx \& Jaspers, 1982). Glutathione can be easily oxidized to the intermolecular disulphide, which subsequently becomes reduced by glutathione reductase (Meister \& Anderson, 1983). The activity of glutathione reductase in cell extracts was induced almost 2-fold by $\mathrm{H}_{2} \mathrm{O}_{2}$ in the exponential growth phase and 4-fold in the stationary growth phase (Table 1). Since glutathione was not detected in Streptomyces clavuligerus, it is possible that the glutathione reductase activity that we measured in $S$. coelicolor is from another reductase that can use glutathione as a substrate. One plausible candidate is thioredoxin reductase (Y. Aharonowitz, Tel Aviv University, Israel, personal communication).

Reduced NADP, produced by glucose-6-phosphate dehydrogenase, can be used as reducing power during protection and repair against oxidative stress. The specific activity of glucose-6-phosphate dehydrogenase in the exponential growth phase was $60 \%$ higher in treated than in untreated cells (Table 1). Little activity was detected in extracts of stationary phase cells.

SOD activity in cell extracts decreased by $70 \%$ following treatment with $100 \mu \mathrm{M}-\mathrm{H}_{2} \mathrm{O}_{2}$ in the exponential growth phase (Table 1). In contrast, SOD activity in $E$. coli (Gregory \& Fridovich, 1973; Hassan \& Fridovich, 1977) and $S$. typhimurium (Christman et al., 1985) was induced following a shift from anaerobic to aerobic conditions or $\mathrm{H}_{2} \mathrm{O}_{2}$ stress. In $E$. coli, the activity of

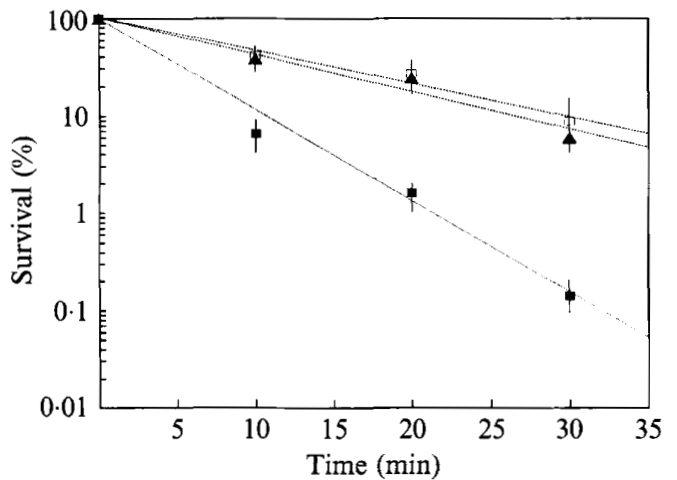

Fig. 3. Survival rate of the wild-type and $\mathrm{H}_{2} \mathrm{O}_{2}$-resistant mutants treated with $20 \mathrm{~mm}-\mathrm{H}_{2} \mathrm{O}_{2}$. Pregerminated spores from the wild-type $(\boldsymbol{\square})$ and from mutants N7 $(\square)$ and $\mathrm{N} 24(\boldsymbol{\Delta})$ were used to inoculate minimal media, and grown for $3 \mathrm{~h}$. Cells were treated with $20 \mathrm{~mm}-\mathrm{H}_{2} \mathrm{O}_{2}$ and then analysed as described in the legend in Fig. 1. Each value is the mean from three experiments. The standard deviation is shown as a bar.

manganese SOD increased during oxidative stress, while that of iron SOD decreased (Hassan \& Fridovich, 1977). Previous investigations showed that manganese SOD was induced by oxygen, redox-cycling compounds in aerobiosis, and iron chelators in anaerobiosis, suggesting that the regulation of SOD activity might be at the transcriptional and the post-transcriptional level (Touati, 1988). Since the superoxide radical is converted irreversibly to $\mathrm{H}_{2} \mathrm{O}_{2}$ in vivo, the failure of $\mathrm{H}_{2} \mathrm{O}_{2}$ to induce SOD activity in $S$. coelicolor is not surprising. The reduction in activity by $\mathrm{H}_{2} \mathrm{O}_{2}$ could have resulted from competition for metals among some $\mathrm{H}_{2} \mathrm{O}_{2}$-induced oxidoreductases, which are metalloproteins.

The difference in the extent of induction depending on the growth phase is consistent with the growth-phasedependent sensitivity to $\mathrm{H}_{2} \mathrm{O}_{2}$ observed in $B$. subtilis (Dowds et al., 1987). This dependence suggests an interaction between the oxidation-inducible and the growth-phase-specific systems.

\section{$\mathrm{H}_{2} \mathrm{O}_{2}$-resistant mutants overexpress several enzyme activities}

As a preliminary to genetic investigation of the regulatory system for the response against oxidation in $S$. coelicolor, we isolated mutants resistant to up to $880 \mathrm{~mm}-\mathrm{H}_{2} \mathrm{O}_{2}$. The mutants arose during NTG mutagenesis at a frequency of about $1 \times 10^{-5}$ per surviving cell. Two mutants showing the highest resistance by disc and strip tests were further characterized. They exhibited marked increases in survival rate against $\mathrm{H}_{2} \mathrm{O}_{2}$ (Fig. 3). Cross-protection against heat shock $\left(50^{\circ} \mathrm{C}\right)$ was also greater in the two mutants compared with the wild-type (data not shown). The specific activity of oxidoreductases in the mutants were measured in the 
Table 2. Comparison of specific activities $\left(U \mathrm{mg}^{-1}\right)$ of defence enzymes in the wild-type and in resistant mutants at different growth phases

Growth phases were as in Table 1. Values are means \pm standard deviations from more than three experiments.

\begin{tabular}{|c|c|c|c|c|c|c|}
\hline \multirow{2}{*}{ Enzyme } & \multicolumn{2}{|c|}{ Wild-type } & \multicolumn{2}{|c|}{ N7 } & \multicolumn{2}{|c|}{ N24 } \\
\hline & Exponential & Stationary & Exponential & Stationary & Exponential & Stationary \\
\hline Catalase & $634 \pm 51$ & $690 \pm 8$ & $5339 \pm 239$ & $2596 \pm 33$ & $1718 \pm 239$ & $1390 \pm 18$ \\
\hline \multicolumn{7}{|l|}{ Peroxidase } \\
\hline Cellular & $2 \cdot 1 \pm 0 \cdot 3$ & $\begin{array}{l}2 \cdot 0 \pm 0 \cdot 3 \\
3 \cdot 8 \pm 0 \cdot 2^{*}\end{array}$ & $2 \cdot 3 \pm 0 \cdot 1$ & $\begin{array}{l}2 \cdot 5 \pm 0 \cdot 1 \\
8 \cdot 8 \pm 0 \cdot 2^{*}\end{array}$ & $2 \cdot 1 \pm 0 \cdot 2$ & $\begin{array}{l}2 \cdot 9 \pm 0 \cdot 1 \\
7 \cdot 4 \pm 0 \cdot 3^{*}\end{array}$ \\
\hline Extracellular & ND & $6 \cdot 8 \pm 0.6^{*}$ & ND & $17 \cdot 6 \pm 1 \cdot 0^{*}$ & ND & $25 \cdot 1 \pm 0 \cdot 8^{*}$ \\
\hline $\begin{array}{l}\text { Glucose-6-phosphate } \\
\text { dehydrogenase }\end{array}$ & $6 \cdot 4 \pm 3 \cdot 0$ & NT & $25 \cdot 1 \pm 0 \cdot 9$ & NT & $9 \cdot 4 \pm 0 \cdot 5$ & NT \\
\hline Glutathione reductase & $508 \pm 233$ & $200 \pm 46$ & $993 \pm 82$ & NT & $947 \pm 61$ & NT \\
\hline Superoxide dismutase & $28 \cdot 5 \pm 6 \cdot 2$ & NT & $21 \cdot 6 \pm 4 \cdot 4$ & NT & $24 \cdot 0 \pm 4 \cdot 4$ & NT \\
\hline
\end{tabular}

NT, ND, ${ }^{*}$, as Table 1.

exponential and stationary growth phases without $\mathrm{H}_{2} \mathrm{O}_{2}$ treatment (Table 2). Both mutants contained higher levels than wild-type cells of all the enzymes tested except SOD.

Catalase activity in mutant N7 was 8-fold higher in the exponential growth phase and 4-fold higher in the stationary growth phase than in wild-type cells. In mutant N24, catalase activity was 3-fold higher in the exponential phase and 2-fold higher in the stationary phase. Intracellular peroxidase activity was about 2-fold higher in the later phase of stationary growth, whereas extracellular activity was 3-4-fold higher in the two mutants. Glutathione reductase activity was about 2 -fold higher in the two mutants. Glucose-6-phosphate dehydrogenase activity was 4-fold higher in N7 and $50 \%$ higher in N24. In both mutants, the increase in catalase activity was much greater than that induced in wild-type cells by $100 \mu \mathrm{M}-\mathrm{H}_{2} \mathrm{O}_{2}$. In the exponential growth phase, the level of catalase in mutants N7 and N24 was 6 times and 2 times greater than the $\mathrm{H}_{2} \mathrm{O}_{2}$-induced level in wildtype cells. SOD activity in the mutants was similar to that in naive wild-type cells. The extent of the increase in peroxidase and glutathione reductase activity in the mutants was similar to the extent of induction by $\mathrm{H}_{2} \mathrm{O}_{2}$ in wild-type cells. When the mutant cells were treated with $100 \mu \mathrm{M}-\mathrm{H}_{2} \mathrm{O}_{2}$, the levels of all five enzymes did not change significantly (data not shown).

Considering the frequency with which these mutants arose, it is unlikely that separate mutations had occurred in the genes for each enzyme affected. The pleiotropic effect of the mutations is possibly due to a change in a regulatory gene controlling the response to $\mathrm{H}_{2} \mathrm{O}_{2}$ stress. It seems plausible to assume that there is global regulation of the oxidative response in $S$. coelicolor, as in E. coli and $S$. typhimurium (Christman et al., 1985; Greenberg \& Demple, 1989; Wu \& Weiss, 1991). In E. coli and $S$. typhimurium, the oxyR (Christman et al. 1989) and sox $R$ (Tsaneva \& Weiss, 1990) genes are known to be required for induction of a response regulon against $\mathrm{H}_{2} \mathrm{O}_{2}$ and superoxide, respectively. OxyR is a transcriptional activator for the genes $k a t G$ (encoding catalase), $\operatorname{ahp} C F$ (encoding alkylhydroperoxide reductase) and gor $A$ (encoding glutathione reductase), whereas SoxR is a global regulator governing nfo (encoding endonuclease IV), zwf (encoding glucose-6-phosphate dehydrogenase) and $\operatorname{sod} A$ (encoding manganese superoxide dismutase). However, since the enzymes induced in resistant mutants N7 and N24 encompass those from both OxyR and SoxR regulons in E. coli, we suppose that the make-up of the peroxide-inducible regulon in $S$. coelicolor is different from E. coli.

This work was supported by a grant from Korea Science and Engineering Foundation (KOSEF) to J.-H. Roe and a KOSEF research grant for SRC (Research Center for Molecular Microbiology, Seoul National University) to Y.-C. Hah. The authors thank Dr Keith Chater for helpful comments on the manuscript.

\section{References}

BASERGA, R. (1989). Measuring parameters of growth. In Cell Growth and Division, pp. 1-16. Edited by R. Baserga. Oxford: IRL Press.

Beauchamp, C. I. \& Fridovich, I. (1971). Superoxide dismutase improved assays and an assay applicable to acrylamide gels. Analytical Biochemistry 44, 276-287.

BEERS, R. F., JR \& SizER, I. W. (1952). A spectrophotometric method for measuring breakdown of hydrogen peroxide by catalase. Journal of Biological Chemistry 195, 276-287.

BoL, K. D. \& YASBIN, R. E. (1990). Characterization of an inducible oxidative stress system in Bacillus subtilis. Journal of Bacteriology 172, 3503-3506.

CADENAS, E. (1989). Biochemistry of oxygen toxicity. Annual Review of Biochemistry 58, 79-110.

Christman, M. F., Morgan, R. W., Jacobson, F. S. \& Ames, B. M. (1985). Positive control of a regulon for defenses against oxidative stress and some heat-shock proteins in Salmonella typhimurium. Cell 41, 753-762.

Christman, M. F., Storz, G. \& Ames, B. M. (1989). OxyR, a positive 
regulator of hydrogen peroxide-inducible genes in Escherichia coli and Salmonella typhimurium, is homologous to a family of bacterial regulatory proteins. Proceedings of the National Academy of Sciences of the United States of America 86, 3484-3488.

DECKER, L. A. (1977). Worthington Enzyme Manual. New Jersey, U.S.A.: Worthington Biochemical Corporation.

Demple, B., HalbrooK, J. \& LinN, S. (1983). Escherichia coli xth mutants are hypersensitive to hydrogen peroxide. Journal of Bacteriology 153, 1079-1082.

Dowds, B. C. A., Murphy, P., McConnell, D. J. \& Devine, K. M (1987). Relationship among oxidative stress, growth cycle, and sporulation in Bacillus subtilis. Journal of Bacteriology 169, 5771-5775.

FARR, B. S. \& Kogoma, T. (1991). Oxidative stress responses in Escherichia coli and Salmonella typhimurium. Microbiological Reviews 55, 561-585.

FARR, B. S., TouATI, D. \& Kogoma, T. (1988). Effects of oxygen stress on membrane functions in Escherichia coli: role of HPI catalase. Journal of Bacteriology 114, 543-548.

FinN, G. J. \& Condon, S. (1975). Regulation of catalase synthesis in Salmonella typhimurium. Journal of Bacteriology 123, 570-579.

GreenibrG, J. T. \& Demple, B. (1989). A global response induced in Escherichia coli by redox-cycling agents overlaps with that induced by peroxide stress. Journal of Bacteriology 171, 3933-3939.

GrEGORY, E. M. \& FrIDOVICH, I. (1973). Induction of superoxide dismutase by molecular oxygen. Journal of Bacteriology 114, 543-548.

Halliwell, B. (1990). How to characterize a biological antioxidant. Free Radicals Research Communications 9, 1-32.

Halliwell, B. \& Gutteridge, J. M. (1989). Protection against oxidants in biological systems: the superoxide theory of oxygen toxicity. In Free Radicals in Biology and Medicine, pp. 86-187. Edited by B. Halliwell \& J. M. Gutteridge. Oxford: Oxford University Press.

Hassan, H. M. \& Fridovich, I. (1977). Enzymatic defense against the toxicity of oxygen and of streptomycin in Escherichia coli. Journal of Bacteriology 129, 1574-1583.

HassetT, D. J. \& CohEN, M. S. (1989). Bacterial adaptation to oxidative stress: implication for pathogenesis and interaction with phagocytic cells. FASEB Journal 3, 2574-2582.

Hopwood, D. A., Bibb, M. J., Chater, K. F., Kieser, T., Bruton, C. J., Lydiate, D. J., Smith, C. P., WaRD, J. M. \& SchrempF, H. (1985). Genetic Manipulation of Streptomyces, a Laboratory Manual. Norwich, UK: John Innes Institute.

IMLAY, J. A. \& LINN, S. (1988). DNA damage and oxygen radical toxicity. Science 240, 1302-1309.

Imlay, J. A., Chin, S. M. \& LinN, S. (1988). Toxic DNA damage by hydrogen peroxide through the Fenton reaction in vivo and in vitro. Science 240, 640-642.
Jenkins, D. E., Schultz, J. E. \& Matin, S. (1988). Starvation-induced cross protection against heat and hydrogen challenge in Escherichia coli. Journal of Bacteriology 170, 3910-3914.

JONES, K. L. (1949). Fresh isolates of actinomycetes in which the presence of sporogenous aerial mycelia is a fluctuating characteristic. Journal of Bacteriology 57, 141-145.

KaPOOR, M. \& SveENIVASAN, G. M. (1988). The heat shock response of Neurospora crassa: stress-induced thermotolerance in relation to peroxidase and superoxide dismutase levels. Biochemical and Biophysical Research Communications 156, 1097-1102.

Meister, A. \& ANDERSon, M. E. (1983). Glutathione. Annual Review of Biochemistry 52, 711-760.

Morgan, R. W., Christman, M. F., Jacobson, F. S., Storz, G. \& AMES, B. N. (1986). Hydrogen peroxide-inducible proteins in Salmonella typhimurium overlap with heat shock and other stress proteins. Proceedings of the National Academy of Sciences of the United States of America 83, 8059-8063.

Murphy, P., Dowds, B. C. A., MCConnell, D. J. \& Devine, K. M. (1987). Oxidative stress and growth temperature in Bacillus subtilis. Journal of Bacteriology 169, 5766-5770.

PEnNINCKx, M. J. \& JASPERs, C. J. (1982). On the role of glutathione in microorganisms. Bulletin de lInstitut Pasteur 80, 291-301.

SARAN, M. \& BoRs, W. (1990). Radical reactions in vivo - an overview. Radiation and Environmental Biophysics 29, 249-262.

SMith, I. K., Vierheller, T. L. \& Throne, C. A. (1988). Assay of glutathione reductase in crude tissue homogenates using $5,5^{\prime}$ dithiobis(2-nitrobenzoic acid). Analytical Biochemistry 175, 408-413.

Storz, G., Jacobson, F. S., Tartaglia, L. A., Morgan, R. W., Silveria, L. A. \& AMES, B. N. (1989). An alkyl hydroperoxide reductase induced by oxidative stress in Salmonella typhimurium and Escherichia coli: genetic characterization and cloning of ahp. Journal of Bacteriology 171, 2049-2055.

Storz, G., Tartaglia, L. A., Morgan, R. W., Farr, S. B. \& Ames, B. N. (1990). Bacterial defenses against oxidative stress. Trends in Genetics 6, 363-368.

TOUATI, D. (1988). Transcriptional and posttranscriptional regulation of manganese superoxide dismutase biosynthesis in Escherichia coli, studied with operon and protein fusions. Journal of Bacteriology 170, 2511-2520.

TSANEVA, I. R. \& WEISS, B. (1990). soxR, a locus governing a superoxide response regulon in Escherichia coli K-12. Journal of Bacteriology $172,4197-4205$.

VanBogelen, R. A., Kelly, P. M. \& Neidhardt, F. C. (1987). Differential induction of heat shock, SOS and oxidation stress regulons and accumulation of nucleotides in E. coli. Journal of Bacteriology 169, 26-32.

Wu, J. \& WeISS, B. (1991). Two divergently transcribed genes, soxR and soxS, control a superoxide response regulon of E. coli. Journal of Bacteriology 173, 2864-2871. 